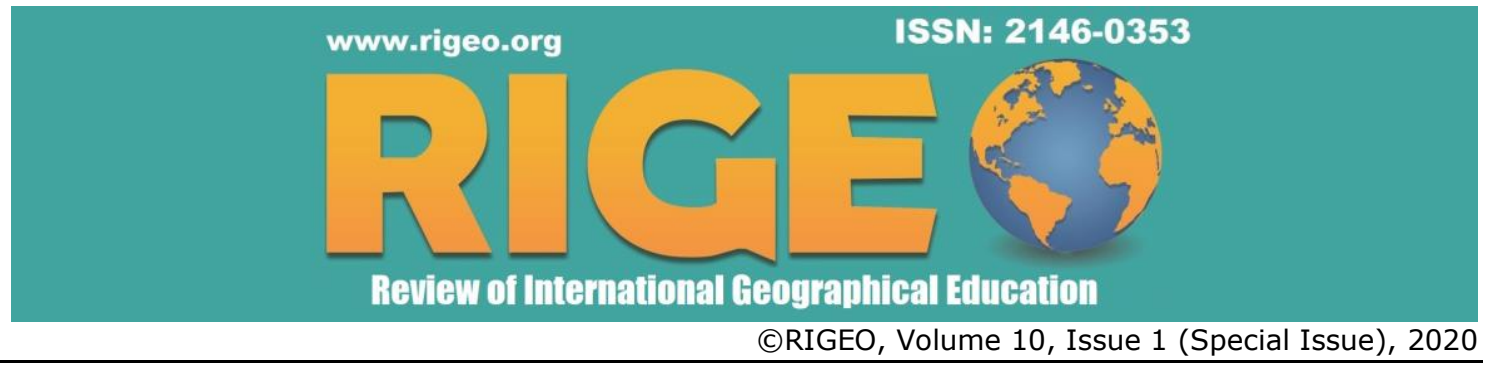

Research Article

Copyright @ RIGEO 2020

To cite this article: Lee, J. (2020). Designing an Inquiry-based Fieldwork Project for Students Using Mobile Technology and Its Effects on Students' Experience. Review of International Geographical Education (RIGEO), 10 (1), Special Issue, 14-39. Retrieved from http://www.rigeo.org/vol10no1/Number1Spring/RIGEO-V10-N1-1.pdf

DOI: 10.33403 rigeo.637666

Submitted: October 24, 2019

Revised: February 07, 2020

Accepted: March 05, 2020

\title{
Designing an Inquiry-based Fieldwork Project for Students Using Mobile Technology and Its Effects on Students' Experience*
}

\author{
Jongwon LEE ${ }^{1}$ \\ Ewha Womans University, Seoul, SOUTH KOREA
}

\begin{abstract}
The objectives of this research are, first, to find mobile technology-informed ways of designing inquirybased fieldwork, in support of students' inquiry processes and, second, to evaluate how a technologyintegrated fieldwork project can affect students' knowledge and experience. In order to achieve these objectives, the study adopted a set of core design principles and guidelines for the creation of inquirybased fieldwork projects, detailing tips and an example (i.e., the Yangdong Village Project) of these principles and guidelines' application. In addition, this study used a questionnaire to determine the influence of the project on students' understanding of the investigation area and their inquiry-related behaviors. It also analyzed conversation between students, to examine how students' learning processes are supported in fieldwork through use of mobile technology. A total of 86 high school students (ages 17-18), from four schools located in the Seoul metropolitan area, participated in the project. The results of the analyses showed that participation in the project helped students become better informed about the area they investigated. While they were conducting the field tasks, they showed more inquiry-driven behaviors, such as being more active and adventurous, more talkative, and more responsible (88.7\%). Technological support for the process of field inquiry was prominent in three situations: location identification, data capture, and monitoring. The functionalities of mobile technology that students used during the field inquiry would reflect not only the characteristics of the task, but also the types of mobile technology involved in the project.
\end{abstract}

Keywords

Inquiry, Fieldwork, Mobile Technology, Inquiry-based Fieldwork, World Heritage Site

\footnotetext{
*A portion of this research was presented in 2. International Congress on Geographical Education (UCEK/ICGE-2019), 3-5 October 2019, Eskişehir-Turkey.

${ }^{1}$ Corresponding author: Dr Jongwon Lee, Ewha Womans University, Department of Social Studies Education, Seoul, South Korea, jongwonlee [at] ewha.ac.kr. ORCID: 000-0002-0724-6287
} 
In South Korea, fieldwork has never been obligatory in the geography curriculum. Even if fieldwork is carried out in schools, it is typically superficial, whereby the students are most often engaged in 'look and see' (Oh \& Lee, 2014). However, recent educational reform in South Korea emphasizing students' engagement, inquiry, and ICT has introduced a favorable environment for geography fieldwork and inquiry-based learning (Lee, 2016). In particular, the reform of the university admission system whereby the power of the college entrance examination is reduced and high school records such as award winning, certificates, and records of volunteer community service are emphasized has encouraged high schools to adopt various innovative learning programs including fieldwork.

Good fieldwork in geography inherently includes many research-proven best practices from across geography education (see Kent, Gilbertson, \& Hunt, 1997). These include working on authentic, real-world, and ill-structured problems in team-based learning (Raath \& Golightly, 2017), or taking a "student centered" approach in which the instructor's role is that of a facilitator rather than source of facts for students. Student-centered learning theory is often grounded in a constructivist pedagogical approach. Another common strategy that can integrate with fieldwork design is inquirybased learning (Oost, de Vries, \& Van der Schee, 2011). Inquiry-based learning systematically engages students in the tasks of posing questions, seeking out relevant information, and evaluating the information in their efforts to answer the original questions. By its nature, inquiry-based learning is a good framework for designing geographical field projects (Roberts, 2013). In particular, Roberts (2013) presented four essential components that geographical inquiry should include. Creating a "need to know" - provoking curiosity and raising questions - is one; selecting an appropriate source of geographical data is another; making sense of that data - describing, analyzing, communicating - is another; reflecting and posing new questions is yet another. These four components have been used as a framework (e.g., Bermingham, 2016; Chang et al., 2012) in designing various field projects for students of geography.

However, inquiry-based learning is not one type of learning and, when applied, it is present in various forms depending on the degree of participation of teachers and learners. In other words, student-centered inquiry-based learning (on one side) is completely up to the learner, while teacher-centered inquiry-based learning (on the other side) emphasizes the teacher's guidance and role. In either case, as students gain more experience with inquiry-based approaches, teachers may increase the scope and difficulty of focus questions, use more open-ended and ill-structured problems, and simultaneously decrease the amount of explicit guidance provided. Therefore, rather than say which form is better, it is important in each case to find the best balance between students' freedom to explore and teachers' provided guidance.

In recent years, there have been an increasing number of attempts to apply mobile technology in support of students' field inquiry processes. These processes include data collection, analysis, and visualization, as well as communication and collaboration in the field (Cochrane \& Bateman, 2010; Fletcher et al., 2007; Looi et al., 2010; McClain \& Zimmerman, 2016; Parsons, 2014). It also has been argued that the use of mobile 
technology will enable field inquiry that was not possible in the past, additionally providing opportunities for students to carry out inquiry processes in more self-directed ways. Thus, incorporating mobile technology in the design of fieldwork projects will have more elements to consider in the future.

Compared to the many possibilities reported in the literature, however, there is little research showing how to design inquiry-based fieldwork projects and integrate technologies to help students' inquiry processes and construction of knowledge. In addition, although there have been a few studies on how technology-integrated fieldwork projects can affect student experience, they are mostly conducted at the postsecondary level (e.g., Fuller \& France, 2016; Welsh, Mauchline, Park, Whalley, \& France, 2013; Fuller; Wellsh, Mauchline, France, Powell, Whalley, \& Park, 2018). Therefore, the current study aims to present a practical design guideline that can be useful in developing a geographical inquiry fieldwork project with mobile-technological support. In detail, the guideline includes the roles of teachers and students, according to the stages of three types of inquiry-based fieldwork, and the factors to consider in fieldwork activity design. The study presents an example (the Yangdong Village Project) which followed the resulting guidelines for fieldwork projects. In addition, because the project provided opportunities through various student tasks to investigate the village's key issues by analyzing the landscape's changes and to interview its residents for local responses, students' knowledge and appraisal of the village were improved. These results offer a test case can show the strength of the design.

Thus, the questions guiding the study are as follows. First, how can we design an inquiry-based fieldwork project that uses mobile technology to investigate sustainable development at a UNESCO World Heritage Site (WHS)? Second, how does participation in an inquiry-based fieldwork project influence students' understanding of the investigation area and inquiry-related behaviors? Third, how can mobile technology foster students' inquiry process in the field?

The rest of the paper is arranged as follows. A conceptual framework consisting of three domains - types of inquiry-based learning, functions of mobile technology, and factors to consider in fieldwork activity design - articulates the rationale behind the project proposed here. Qualitative and quantitative data collection methods come under discussion along with their results. The results are summarized and reported according to each research question. The paper concludes with an overall discussion of the results obtained.

\section{Conceptual Framework}

\section{Types of Inquiry}

Inquiry should be accessible for view as a continuum that combines levels of student and teacher participation with inquiry strategies. Several frameworks have offered ways to distinguish the extents to which teachers can enable learners to take part in the construction of knowledge. For example, Roberts (2013) classified "closed," "framed," and "negotiated" styles which stand for a progression away from teacher-controlled 
learning. A "closed" approach to inquiry-learning involves questions, data, activities, and conclusions selected by teachers, with knowledge outcomes tightly under teachers' control. A "framed" approach involves the teacher inducting students into ways of constructing geographical knowledge, with limited guidance from the teacher. A "negotiated" approach involves students deciding what questions to investigate, under guidance from the teacher, whose role is to provide that guidance along with support, as the students identify appropriate methods and procedures and finally reach their own conclusions. Marshall, Smart, \& Horton (2009) suggested similar ideas. They named a set of levels of the inquiry process in a classroom: pre-inquiry (level 1), developing inquiry (level 2), proficient inquiry (level 3), and exemplary inquiry (level 4). In this schema, Level 1 corresponds to be a more traditional, teacher-dominated classroom where students tend to be passive recipients of information. Level 4 , by contrast, emerges when the teacher is able to facilitate learning experiences where the students successfully and consistently engage in rigorous, content-embedded inquiry learning experiences.

In fieldwork study, it has been suggested that "guided inquiry" helps students learn content knowledge and master skills more efficiently, prevents the sense of time wasted when experiencing failure (Kirschner, Sweller, \& Clark, 2006; Trautmann, MaKinster, $\&$ Avery, 2004). In a guided inquiry, students receive a question, but they may or may not have a prescribed procedure to follow; in an "open inquiry," students develop a research question, collect data, and finally answer the question. In comparison with guided inquiry, open inquiry increases students' sense of ownership and responsibility when working on projects (Reid \& Yang, 2002; Sadeh \& Zion, 2012). Which type of inquiry is more suitable for fieldwork depends on the teacher's experience, the learner's inquiry scaffolding, and the nature of the inquiry task.

As geography fieldwork projects often consist of three major stages (pre-fieldwork, fieldwork, and post-fieldwork), it is important to account for the roles of teachers and students in each stage. Table 1 summarizes the spectrum of options that can be employed by teachers and their students at the main stages of inquiry-based fieldwork (Roberts, 2013; Marshall, Smart, \& Horton, 2009). This can be a useful guide for educators in developing fieldwork projects for students with various educational needs and experiences.

Table 1

Three types of inquiry-based fieldwork: roles of teachers and students, in stages

\begin{tabular}{llll}
\hline & $\begin{array}{c}\text { Most teacher guidance } \\
\text { (Teacher "informs") }\end{array}$ & $\begin{array}{c}\text { Moderate teacher } \\
\text { guidance } \\
\text { (Teacher "guides") }\end{array}$ & $\begin{array}{c}\text { Least teacher guidance } \\
\text { (Teacher "helps") }\end{array}$ \\
\hline Posing & $\begin{array}{l}\text { - Teacher directly } \\
\text { questions } \\
\text { question for } \\
\text { investigation }\end{array}$ & $\begin{array}{l}\text { Teacher uses guiding } \\
\text { questions and / or } \\
\text { feedback to help } \\
\text { students devise } \\
\text { questions }\end{array}$ & $\begin{array}{l}\text { Teacher helps students } \\
\text { formulate inquiry } \\
\text { questions }\end{array}$ \\
\hline Planning & $\begin{array}{c}\text { - Teacher decides what } \\
\text { data to collect and how }\end{array}$ & $\begin{array}{l}\text { - Teacher guides } \\
\text { students to think about }\end{array}$ & $\begin{array}{c}\text { - Teacher helps } \\
\text { students: a) specify / }\end{array}$ \\
\hline
\end{tabular}




\begin{tabular}{|c|c|c|c|}
\hline & $\begin{array}{l}\text { to collect them } \\
\text { - Teacher directly } \\
\text { supplies equipment or } \\
\text { tools (e.g., } \\
\text { questionnaires) for data } \\
\text { collection, and tells } \\
\text { how to use them }\end{array}$ & $\begin{array}{l}\text { what data to collect } \\
\text { and how they can } \\
\text { collect them } \\
\text { Even when using the } \\
\text { teacher-provided } \\
\text { method, students need } \\
\text { to understand clearly } \\
\text { why they use such a } \\
\text { method }\end{array}$ & $\begin{array}{l}\text { use relevant data for } \\
\text { their investigation; b) } \\
\text { design procedure }\end{array}$ \\
\hline $\begin{array}{l}\text { On site } \\
\text { data } \\
\text { collection }\end{array}$ & $\begin{array}{l}\text { Teacher often shows } \\
\text { how to collect data } \\
\text { Teacher controls and } \\
\text { monitors progress of } \\
\text { data collection }\end{array}$ & $\begin{array}{l}\text { - Teacher might present } \\
\text { a list of methods, } \\
\text { which students can add } \\
\text { to or adjust based on } \\
\text { local situations } \\
\text { - Although teacher } \\
\text { monitors students' } \\
\text { progress, managing } \\
\text { progress is students' } \\
\text { responsibility }\end{array}$ & $\begin{array}{l}\text { - Teacher helps students } \\
\text { to lead data collection } \\
\text { in field, but students } \\
\text { can, if needed, seek } \\
\text { advice or support from } \\
\text { teacher } \\
\text { - Students can actively } \\
\text { adjust method during } \\
\text { data collection }\end{array}$ \\
\hline $\begin{array}{l}\text { Making } \\
\text { sense }\end{array}$ & $\begin{array}{l}\text { - Teacher tells how to } \\
\text { organize, analyze, } \\
\text { express, and interpret } \\
\text { collected data } \\
\text { - Teacher presents or } \\
\text { shows patterns and } \\
\text { relationships in data, or } \\
\text { explains, using results }\end{array}$ & $\begin{array}{l}\text { - Although teacher } \\
\text { presents how to } \\
\text { organize, analyze, } \\
\text { express, and interpret } \\
\text { collected data, students } \\
\text { need to discuss } \\
\text { advantages and } \\
\text { disadvantages of } \\
\text { various methods and to } \\
\text { understand why they } \\
\text { would use each } \\
\text { Teacher guides } \\
\text { students to find } \\
\text { patterns and } \\
\text { relationships, or to } \\
\text { supply explanation, } \\
\text { from data }\end{array}$ & $\begin{array}{l}\text { - Teacher helps students } \\
\text { organize, analyze, } \\
\text { express, and interpret } \\
\text { data to the best of their } \\
\text { ability } \\
\text { - Students encouraged to } \\
\text { be critical of their } \\
\text { interpretations and } \\
\text { explanations }\end{array}$ \\
\hline $\begin{array}{l}\text { Outcome / } \\
\text { Reflection }\end{array}$ & $\begin{array}{l}\text { - Teacher decides type of } \\
\text { final product for } \\
\text { students to produce, } \\
\text { and evaluation criteria } \\
\text { - Teacher directly tells } \\
\text { how inquiry process } \\
\text { can improve }\end{array}$ & $\begin{array}{l}\text { - Teacher presents } \\
\text { choices of final output } \\
\text { that students can } \\
\text { produce } \\
\text { - Teacher presents } \\
\text { guiding questions } \\
\text { enabling students to } \\
\text { reflect on their inquiry } \\
\text { processes }\end{array}$ & $\begin{array}{l}\text { - Students can produce } \\
\text { diverse types of output } \\
\text { through consultation } \\
\text { with teacher } \\
\text { - Teacher helps students } \\
\text { evaluate their inquiry } \\
\text { processes critically }\end{array}$ \\
\hline
\end{tabular}




\section{Mobile Technology and Inquiry-based Fieldwork}

Mobile devices have been increasingly useful in educational applications contextually focused on supporting fieldwork methods, owing to unique optimizations for portability, social interactivity, context sensitivity, connectivity, and individuality (Klopfer, Squire, \& Jenkins, 2008; Patten, Sánches, \& Tangney, 2006). This is especially true for inquiry-based fieldwork, where students are often challenged to take the lead throughout inquiry, data collection, and collaborative problem-solving in the field (Chatterjea, 2012; Cliffe, 2017). Song, Wang, \& Looi (2012, p. 683) summarized unique benefits of mobile technologies used in the fieldwork as follows.

A variety of embedded functions such as camera, recording, note-taking and online and / or downloaded resources in the mobile devices have been used in the field trips to support "concrete experience" by capturing the features of plants or animals to record the authentic phenomena; support "reflective observation" by taking down "just-in-time" notes and recording timely observational information, and access online or downloaded resources to aid observation; support "abstract conceptualization" by visiting and organizing the captured and recorded information when reporting the field trip observations, and support "testing in new situations" by re-visiting the information and making use of the conceptualized knowledge gained in the field trip.

Affordances that mobile devices have, for capturing moments of curiosity, can help to increase contextualized learning and awareness of what is happening in the surrounding world. Beyond the sensors installed on mobile devices for audiovisual and GPS functions, many applications allow the users to collect and measure various geographical data during fieldwork. These include sound (or noise), distance, angle, temperature, and speed (Jarvis et al., 2016; Jong \& Tsai, 2016; Medzini, Meishar-Tal, \& Sneh, 2015; Welsh et al., 2015).

In addition, mobile applications help students create maps and graphs using data they collected. These capabilities for capturing and visualizing data enable users to find patterns and relationships among data and have exciting potential to enhance geographical field inquiry (Chang et al., 2012; Hedberg, 2014; Hsu \& Chen, 2010; Marra et al., 2017). Also, supporting data collection in a variety of forms (e.g., textual, photographic, and / or audiovisual) empowers students to produce their reports more vividly and realistically than with more traditional projects (Jong \& Tsai, 2016). One of the main advantages of mobile technology, however, is that it gives learners independence to explore their environment, and to learn in their own time and at their own pace (Hedberg, 2014). Thus, some authors consider that the portability of the mobile platform implies that learning with such devices will find natural contextualization.

Mobile devices are also suited for collaborative inquiry because they empower learners to share their experience and information with their peers (Looi et al., 2010; Patten, Sánches, \& Tangney, 2006). Fieldwork often involves small-group activities conducted in geographically separate locations. If all students are networked via mobile devices, each can readily share descriptions and interpretations of geographical phenomena with peers and instructors (Chang et al., 2012; Chatterjea, 2012; Goh et al., 2012; Yang \& Lin, 2010). In addition, a shared platform for data collection enables 
rapid compilation from several student groups to a single database (Chatterjea, 2008). Furthermore, mobile technologies allow students to collect data at multiple sites concurrently or at the same site over time. Moreover, according to Suárez et al. (2018), if students are wirelessly connected, the progress of data collection can be checked instantaneously through mobile devices.

\section{Factors to Consider in Fieldwork Activity Design}

One of the key challenges in designing inquiry-based geographical fieldwork projects is to engage students in inquiry through authentic issues and problems belonging to the area under investigation (Johnson, 2003). Participants should be involved, by exploring the area on their own, in a range of activities involving direct experience of data collection for their field task, collaboration with colleagues, and interpretation of the landscape as well as interaction with residents. After completing such activities, students should be able to not only understand the geography of the investigated area, but also improve their inquiry skills. Therefore, designing student activities for inquiry-based fieldwork requires a comprehensive understanding of inquiry-based learning (from questions to discovery, experience and collaboration) and the area for investigation, as well as instructional and technical scaffolding (transfer, technology, and metacognitive scaffolding). The following are some key questions which educators must consider while they design fieldwork activities for students.

- Inquiry questions: Is each question of such a nature that it answerable in following a data collection process?

- Discovery experience: Are the inquiry questions similar in nature to those asked by experts, i.e., professional geographers?

- Investigation area: Does each inquiry question consider issues or other points of interest such as landscape, locality, environment, etc.?

- Collaboration: Do students in their small groups allow different thoughts about, or answers to, the inquiry questions? Does the task require members in a small group to collaborate?

- Transfer: In the field, do students use knowledge gained in the classroom? In the classroom, do students use the data collected in the field?

- Technology: Does the provided technology support the projected learning, through data collection, organization, analysis, visualization, and communication?

- Scaffolding: Is instructional scaffolding in place, to support student inquiry as planned?

Each of these seven points will next receive some discussion. As a first consideration, the inquiry questions should not be answerable by students in the classroom without collecting data from outside: otherwise, there is no point in conducting the fieldwork. In addition, sufficient data should be collectable under the given conditions (e.g., time of stay) within the study area (Roberts, 2013). Meanwhile, a key inquiry question can break down into a subset of workable questions or guiding questions. Each guiding question should relate to a particular student activity, so that completing each sub-activity enables students to answer the corresponding question. 
Secondly, student tasks in the field should supply experiential learning exercise that emphasizes the inquiry or discovery process. What discovery is, for geography students, is often rediscovery through the geographical research, of what is already known. But it is still important for students to go through the steps of constructing their own embodied knowledge through the opportunity to think and do like geographers (Bednarz, Heffron, \& Huynh, 2013; Tally, 2007). In this regard, Perkins (2009) argues that students should be given opportunities to "play the whole game" (25). In these experiences it is possible for them to experience junior versions of how knowledge is created within specific disciplines, rather than merely learning about fields of knowledge as subject matter (i.e., facts and definitions).

Thirdly, student tasks should address the critical issues or problems of the area selected for investigation: they should involve more than just practicing students' inquiry skill in some particular place. In other words, the topic of a student task needs to show why students need to collect data "there" (Lee \& Catling, 2016).

Fourthly, participants should be placed in groups and required to collaborate in order to discuss the issues constantly, and to benefit from one another's experience and knowledge. To do that, each task needs to allow different possible answers, and to encourage students to compare their ideas. Through interactions such as accepting, adapting, or ignoring others' contributions, students build new knowledge (Dillenbourg, 1999; Patten et al., 2006). This knowledge is co-constructed.

Fifthly, fieldwork activities should bring opportunities for students to transfer basic content knowledge from the classroom to the field setting. Conversely, when students return to the classroom from the field (Sweller \& Cooper, 1985), their activities should call on them to transfer newly gained knowledge from the field. Furthermore, students should be able to apply their knowledge and inquiry skills from the fieldwork to other tasks outside the school.

Sixthly, educators also must find the key to match the unique features of mobile technology to the specific pedagogical challenges of their planned inquiry-based fieldwork. This may include exploring the investigation area on their own, interacting with local people, and interpreting landscapes (France et al., 2015; Hedberg, 2014; Patten et al., 2006). Especially, it is important to consider elaborate designs in learning activities based on mobile devices, such as mechanisms for enhancing data collection and management. Explanatory strategies are also important, along with continuous reflection specifically related to what they have observed or learned in the field, and data sharing and communication with colleagues who are spatially remote (Sung, Hwang, \& Chang, 2016).

Lastly, scaffolding makes inquiry-based learning more effective for students by breaking up complex and difficult tasks into more manageable and accessible tasks, each of which falls within the students' zone of proximal development (Vygotsky 1978). Scaffolding can take a variety of forms; for example, the teacher can scaffold the structure of tasks or the level of technology, to lessen complexity as the student completes each task or level. If students experience difficulty in posing effective questions early in the inquiry process, the teacher can use flexible scaffolding by 
providing examples, analogies or feedback, so students can construct their own questions (Kwan \& So, 2008; Webster et al., 1996).

\section{Example: Yangdong Village Project}

Inquiry questions and activities. An inquiry-based fieldwork project was designed following the guidelines suggested. The project was designed for secondary school students in South Korea, to align their inquiry activities with the use of mobile technologies and the issues of a historic village (i.e., Yangdong Village). Yangdong Village has well-preserved historic buildings and layouts which represent the aristocratic Confucian culture of the Joseon period (1392-1897). Residents also keep up a Confucian lifestyle and other cultural legacies of the distant past. For these reasons, the village was chosen as a World Heritage Site (WHS) under the title "Historic Villages of Korea." While the designation of WHS brought considerable benefit to the local tourism industry, Kang, Kim \& Park (2011) reported, it also raised concerns about preserving the village's uniquely serene atmosphere.

The purpose of the fieldwork project was to allow students to understand issues and problems faced by this traditional village recently designated as a WHS, and to practice inquiry skills through the designed process of field inquiry. The main tasks of the participating students were to investigate the impacts of tourism on the village, and to suggest sustainable ways in which the village could develop. More analytically, the three key questions framing the structure of the project are as follows:

- What are the traces of impact from WHS designation on the village?

-What features need to change in the village, and what features should remain the same?

- Are the village residents satisfied with the recent changes?

Each of the key questions is associated with one student task (Table 2). Completing these tasks enables students to collect data necessary to answer the three key questions.

Table 2

Structure of three inquiry questions and their corresponding field inquiry tasks

\begin{tabular}{|c|c|}
\hline Key question & Student field task \\
\hline $\begin{array}{l}\text { What are the traces of } \\
\text { impact from WHS } \\
\text { designation on the } \\
\text { village? }\end{array}$ & $\begin{array}{l}\text { Task } 1 . \text { Determine and map the functional changes of all } \\
\text { traditional houses in the village. } \\
\text { Not changed } \\
\text { Changed (e.g., used for a restaurant) } \\
\text { Newly built }\end{array}$ \\
\hline $\begin{array}{l}\text { What features need to } \\
\text { change in the village, and } \\
\text { what features should } \\
\text { remain the same? }\end{array}$ & $\begin{array}{l}\text { Task 2. Determine and map the features that need change or } \\
\text { preservation. } \\
\text { - Tangible features for preservation } \\
\text { - Intangible features for preservation } \\
\text { - Tangible features for removal / change }\end{array}$ \\
\hline
\end{tabular}




\begin{tabular}{ll}
\hline $\begin{array}{l}\text { Are the village residents } \\
\text { satisfied with the recent } \\
\text { changes? }\end{array}$ & $\begin{array}{l}\text { Task 3. Conduct interviews with village residents about the } \\
\text { impact of the WHS listing, and about changes needed for the } \\
\text { village's future. }\end{array}$ \\
\hline
\end{tabular}

The mobile technologies of ArcGIS Collector and Google Forms, respectively, supported students' data collection for Tasks 1 and 2, and their data management for Task 3. Collector is a data collection app based on a geographic information system (GIS). It runs on iOS and Android devices and is well suited for a fieldwork-based learning task because of its mobility and its support for location-based data collection. Similarly, Google Forms made it easy for students to manage answers to a questionnaire while interviewing residents of the village. Students received iPads equipped with Collector and Google Forms, along with portable Wi-Fi hotspots in the village.

To carry out Task 1, determining the possible traces from WHS designation and tourism on the village, students surveyed all (about 300) traditional houses (Hanok) in the village for functional changes. Students needed to find traditional houses displayed on the map in Collector, determine their functional changes, and select one of the three predefined colors to encode in Collector: black ("not changed"), gray ("changed") or white ("newly built"). For example, if a traditional house had become a B\&B, the students should encode that house using gray; if they found newly built public restrooms whose construction may be due to the rise in visitor numbers, they marked in white (Figure 1. A-C).

To complete Task 2, students needed to show the village's features most eligible for preservation or removal, mapping them in Collector. For example, if a student considered a vending machine to be too modern for the village, s/he would record the vending machine by camera and, using Collector, upload the picture with an explanation specifying reason and its exact location on the map. While uploading the photo, students had to encode relevant values by color (e.g., red for features they would remove) (Figure 1. D-F).

For Task 3, students conducted interviews with village residents, to explore the impact of WHS designation on the village, the residents' views on how to improve the village as living space, and how to attract more tourists. Students use a set of 3-point Likert scale questions (e.g., "Please rate the extent to which you agree with the following statements that indicate changes in Yangdong Village after WHS designation" - concerning employment opportunities, privacy, etc.). They also used open-ended questions (e.g., "What needs to be undertaken to improve the residential village?") (Figure 2. E). 


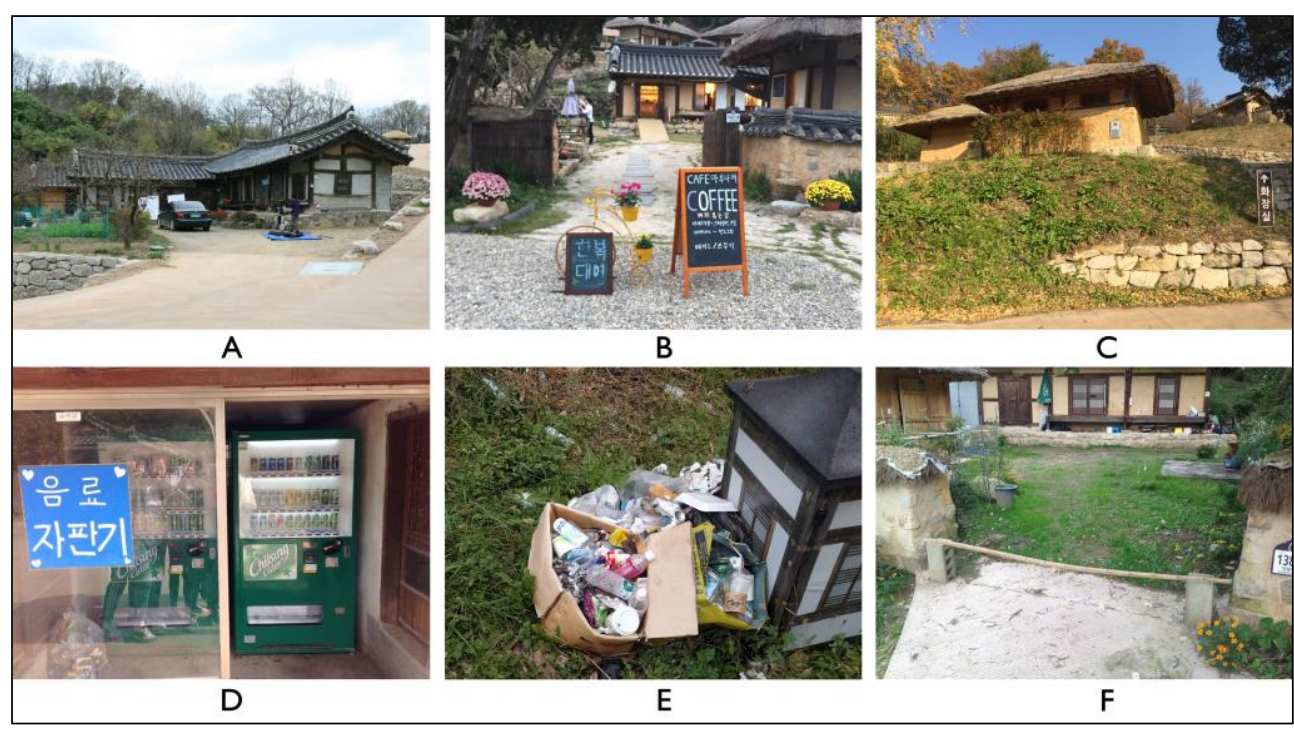

Figure 1. Overview of student tasks 1 and 2

Sample buildings students found for Task 1, including a traditional house for residence (A), one used for a coffee shop (B), and a newly built traditional thatched cottage housing restrooms (C). Sample features students identified for Task 2 included features to change, marked "vending machine - should be gone" (D) and "unmanaged trash" (E). Another example showed an intangible feature to preserve: "open gate symbolizing a high level of trust between local residents" (F).

Stages of project. The project consisted of three stages: pre-fieldwork, fieldwork, and post-fieldwork; it was designed in accordance with the four components / stages of inquiry proposed by Roberts (2013) as shown in Table 3. The project featured "moderate teacher guidance", designed to represent the intermediate of the three types of inquiry (see Table 1).

Table 3

Key student activities and instructional scaffoldings for three stages of Yangdong Village Project

\begin{tabular}{|c|c|c|}
\hline $\begin{array}{l}\text { Fieldwork } \\
\text { stage }\end{array}$ & Student activity & $\begin{array}{l}\text { Instructional and technological } \\
\text { support }\end{array}$ \\
\hline \multirow[t]{2}{*}{$\begin{array}{l}\text { Pre- } \\
\text { fieldwork: } \\
\text { Creating a } \\
\text { "need to } \\
\text { know" }\end{array}$} & $\begin{array}{l}\text { - Observe sustainability issues in } \\
\text { Yangdong Village by watching } \\
\text { video content and playing a card- } \\
\text { sorting game } \\
\text { - Share inquiry questions } \\
\text { - Develop interview questions }\end{array}$ & $\begin{array}{l}\text { - Suggest questions to help students } \\
\text { name issues } \\
\text { - Supply sample interview questions } \\
\text { for guidance }\end{array}$ \\
\hline & $\begin{array}{l}\text { - Practice data collection using } \\
\text { ArcGIS Collector }\end{array}$ & - Demonstrate how to use technology \\
\hline $\begin{array}{l}\text { Fieldwork: } \\
\text { Selecting } \\
\text { geographic } \\
\text { al data }\end{array}$ & $\begin{array}{l}\text { - Task 1: Investigate functional } \\
\text { changes of traditional houses } \\
\text { - Task 2: Find and map features to } \\
\text { preserve or change }\end{array}$ & $\begin{array}{l}\text { - Respond to difficulties or problems } \\
\text { with technology use } \\
\text { - Monitor students' data collection } \\
\text { progress via technology }\end{array}$ \\
\hline
\end{tabular}




\begin{tabular}{lll}
\hline & $\begin{array}{l}\text { - Task 3: Conduct interviews with } \\
\text { village residents }\end{array}$ & $\begin{array}{l}\text { - Encourage and guide student } \\
\text { activities in field (e.g., interviews } \\
\text { with residents) }\end{array}$ \\
\hline & $\begin{array}{l}\text { Create a final product (e.g., ESRI } \\
\text { story map) with survey and }\end{array}$ & $\begin{array}{l}\text { Demonstrate how to create a story } \\
\text { map; present examples }\end{array}$ \\
$\begin{array}{l}\text { Post- } \\
\text { fieldwork: }\end{array}$ & $\begin{array}{l}\text { interview data, photos, and } \\
\text { Making }\end{array}$ & $\begin{array}{l}\text { Supply guiding questions to help } \\
\text { students' reflection }\end{array}$ \\
sense of & Present and share findings and & \\
data; & analysis & \\
Reflection & $\begin{array}{l}\text { Evaluate and improve on data } \\
\text { collection, analysis, and }\end{array}$ & \\
& presentation \\
\hline
\end{tabular}

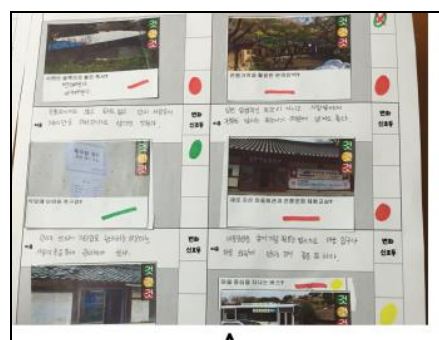

A

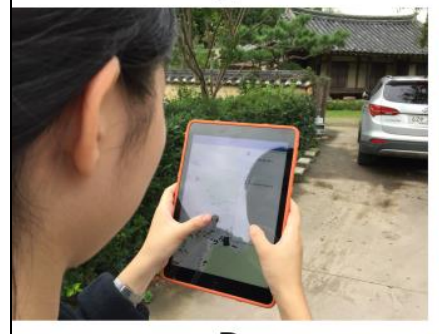

$\mathrm{D}$

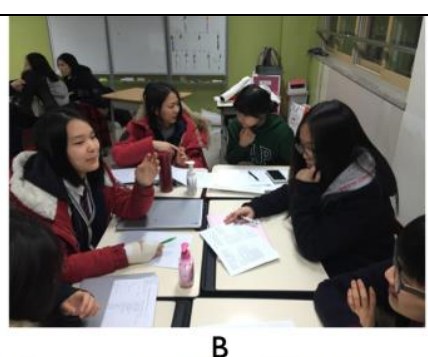

B

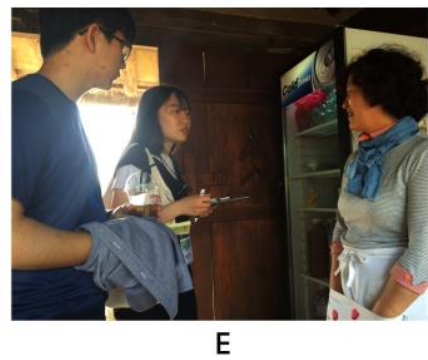

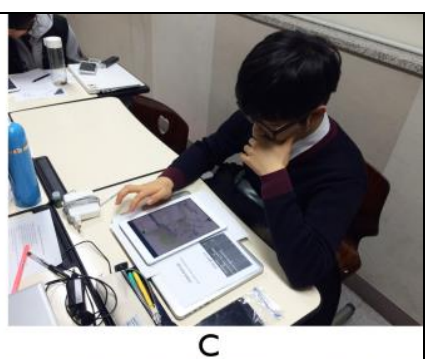

C

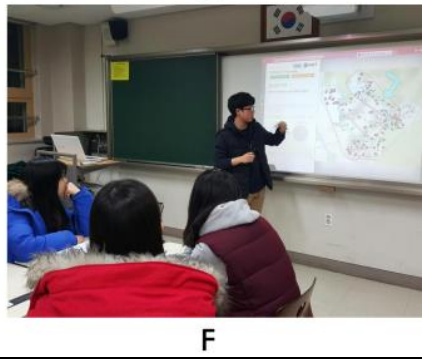

Figure 2. Overview of fieldwork project.

During pre-fieldwork study, students took part in a card-sorting activity (A), constructed a survey questionnaire (B), and practiced using the Collector (C). During on-site field study, students collected data using iPads (D) and conducted interviews with residents (E). During post-field study, students shared their findings with each other through story maps (F).

During the pre-fieldwork, students built up knowledge about Yangdong Village and its issues, especially related to the impact of WHS designation, by watching a video and taking part in a card-sorting activity. The card-sorting activity, which simulated Task 2 , allowed students to become familiar with data collection activity before the actual field sessions started (Figure 2. A). The students also practiced using the Collector during their pre-field study (Figure 2. C). The fieldwork was an intense one-day activity in which the students needed to complete three data collection tasks in the village. Students worked in their groups of four or six, to collect data within four subdivisions (A-D) of the village. Each group was again divided into two or three sub-groups.

Assigned segments were sufficiently small for ease of work, since Task 1 required groups to investigate the entire area of the village in considerable detail. One iPad with a portable Wi-Fi was given to each pair of students during the data-collection period. 
During the post-field stage of their study, the groups combined their individual findings and shared them with the other groups. Students showed their understanding and their findings by creating a story map using data collected in the village (Figure 2. F). Story maps are interactive maps combined with text and other multimedia contents including pictures, videos, and websites. The story maps proved an effective way for students to express the spatial stories attached to their projects.

\section{Methods}

\section{Participants}

A total of 86 high-school students (ages 17-18) participated in the project, representing four schools (Schools A-D) located in the Seoul metropolitan area. Recruitment for the project took place at the individual schools. The number of participants per school was 19,26, 23, and 18, respectively, for schools A-D.

\section{Data Collection and Analysis}

The research design used for this study was mixed methods as described by Creswell and Clark (2017). The theory that underpins mixed methods research presumes that the collection and analysis of data consists of the combination of both qualitative and quantitative methods. This study used a mixed research method to collect and analyze quantitative and qualitative data from 86 participating students. To determine how the use of mobile technology supported students' learning processes in the field (Research question \#3), student interactions were recorded and analyzed from within each small group during the fieldwork. Audio recordings were collected only from the students of school A $(\mathrm{N}=19)$ and were approximately three hours per small group, most groups consisting of two students. The thematic analysis focused mainly on those types of problems the students encountered in the field, and on how students used mobile technology to solve those problems and to support their field inquiry. The basic types of mobile technology with potential for supporting fieldwork were found through previous studies (e.g., Medzini, Meishar-Tal, \& Sneh, 2015), and then corrected and supplemented through comparison with the students' audio data. The current study categorized functions of mobile technology support for fieldwork into four major groups as follows: location guidance, data capture, metacognition, and communication (Table 4).

Table 4

Types of mobile support

\begin{tabular}{lll}
\hline Main category & Sub-category & Definition \\
\hline $\begin{array}{l}\text { Location } \\
\text { guidance }\end{array}$ & $\begin{array}{l}\text { Location } \\
\text { identification }\end{array}$ & $\begin{array}{l}\text { Mobile devices equipped with GPS allow users to } \\
\text { obtain information relevant to a location }\end{array}$ \\
\cline { 2 - 3 } Doute planning & $\begin{array}{l}\text { Mobile devices with GPS capability enable users to } \\
\text { plan and follow the best route to their destination }\end{array}$ \\
\hline \multirow{3}{*}{ Data capture } & Data capture & $\begin{array}{l}\text { The built-in camera, voice recorder and writing } \\
\text { applications are useful for documenting information }\end{array}$ \\
\cline { 2 - 3 } & $\begin{array}{l}\text { Data editing \& } \\
\text { transmission }\end{array}$ & $\begin{array}{l}\text { Mobile devices on a wireless network allow users to } \\
\text { upload the data on local devices or remote servers, }\end{array}$ \\
\hline
\end{tabular}




\begin{tabular}{|c|c|c|}
\hline & & and to access, edit, and manage them \\
\hline & $\begin{array}{l}\text { Data } \\
\text { interpretation }\end{array}$ & $\begin{array}{l}\text { The ability of mobile devices to visualize data in a } \\
\text { variety of forms helps users find distributions, } \\
\text { patterns, or relationships among data }\end{array}$ \\
\hline \multirow{2}{*}{ Metacognition } & $\begin{array}{l}\text { Monitoring \& } \\
\text { Clarification }\end{array}$ & $\begin{array}{l}\text { Real-time mapping and data visualization features of } \\
\text { mobile devices allow users to check ongoing } \\
\text { progress including clarification of complex issues or } \\
\text { situations, and comparisons to their own progress }\end{array}$ \\
\hline & $\begin{array}{l}\text { Planning based } \\
\text { on data }\end{array}$ & $\begin{array}{l}\text { Mobile devices help users formulate specific action } \\
\text { plans (i.e., role definition and allocation in early } \\
\text { stage) or to change strategies based on their self- } \\
\text { evaluated progress }\end{array}$ \\
\hline Communication & Communication & $\begin{array}{l}\text { Smartphones serve as means of communication } \\
\text { through actual voice conversations and text } \\
\text { messaging }\end{array}$ \\
\hline
\end{tabular}

To determine the influence of the project on students' understanding of the investigation area, and their inquiry-related behaviors (Research question \#2), there was a student questionnaire. After completing the project, the participants responded to statements illustrating their understanding, such as "I became more aware of Yangdong Village after this project." There were also statements eliciting comments about their attitude toward the village, for example, "After completing this project, Yangdong Village became more valuable to me." Other statements invited commentary on inquiryrelated behaviors, e.g., "I talked more during the fieldwork than in regular classroom lessons." Using a Likert scale ranging from "strongly agree" to "strongly disagree," these data were collated with qualitative data obtained from the students' conversations, to illustrate probable changes in knowledge and attitude associated with project participation.

Lastly, field data (i.e., photos and memos) were examined from what the participants had collected and uploaded via Collector. The researcher also collected observations and field notes throughout the study.

\section{Results}

\section{Inquiry-based Fieldwork and Participants' Understanding}

Understanding of investigation area. Most participants reported that the project had brought about positive changes in their knowledge about and attitude towards the village. For instance, $94.0 \%$ agreed or strongly agreed that they had "become more aware of the village" through this project. $83.6 \%$ of them agreed or strongly agreed that they "could suggest a sustainable way for the village to develop." Furthermore, over 90\% agreed after they completed the project that "Yangdong Village had become more valuable" to them (Table 5). 
Table 5.

Questionnaire results: participants' understanding and behavior $(N=86)$

\begin{tabular}{|c|c|c|c|c|c|}
\hline Question & $\begin{array}{l}\mathrm{SD} \\
\%\end{array}$ & $\mathrm{D} \%$ & $\mathrm{~N} \%$ & $\mathrm{~A} \%$ & $\begin{array}{l}\text { SA } \\
\%\end{array}$ \\
\hline 1. I became more aware of Yangdong Village. & 0.0 & 0.0 & 5.9 & 41.2 & 52.9 \\
\hline $\begin{array}{l}\text { 2. After I completed the project, Yangdong Village was } \\
\text { more valuable to me. }\end{array}$ & 0.0 & 0.0 & 7.2 & 34.9 & 57.8 \\
\hline $\begin{array}{l}\text { 3. I can suggest a sustainable way for Yangdong } \\
\text { Village to develop. }\end{array}$ & 0.0 & 2.3 & 14.1 & 51.8 & 31.8 \\
\hline $\begin{array}{l}\text { 4. I became a more active learner in the field than in } \\
\text { the classroom. }\end{array}$ & 0.0 & 2.3 & 13.6 & 44.3 & 39.8 \\
\hline $\begin{array}{l}\text { 5. I became more adventurous while I was working in } \\
\text { my team. }\end{array}$ & 2.3 & 1.1 & 15.9 & 52.3 & 28.4 \\
\hline $\begin{array}{l}\text { 6. I talked more during the fieldwork than in the } \\
\text { classroom. }\end{array}$ & 0.0 & 3.4 & 17.0 & 39.8 & 39.8 \\
\hline $\begin{array}{l}\text { 7. I felt more responsibility for my studies while doing } \\
\text { fieldwork than I did in the classroom. }\end{array}$ & 0.0 & 3.4 & 7.9 & 43.2 & 45.5 \\
\hline $\begin{array}{l}\text { 8. Collaboration was an essential requirement to } \\
\text { complete the tasks of this project. }\end{array}$ & 0.0 & 0.0 & 0.7 & 37.6 & 55.3 \\
\hline 9. I learned various field investigation methods. & 0.0 & 0.0 & 10.6 & 52.9 & 36.5 \\
\hline 10. My ability to use technology improved. & 0.0 & 1.2 & 20.9 & 50.0 & 27.9 \\
\hline
\end{tabular}

*SA=Srongly Agree, A=Agree, N=Netural, D=Disagree, $\mathrm{SD}=$ Strongly Disagree

The positive responses given should be associated with the series of activities from pre-fieldwork, to on-site field study and then post-field study. Prior to the field visit, participants had opportunities to gain understanding of the issues facing the village and its sustainability, through a variety of activities ranging from watching videos and sorting cards to developing the interview questions. Knowledge gained from the prefieldwork activities was available for use as the basis for activity in the field. A deeper understanding of the village seems to have developed during the three field tasks. Task 1 required participants to analyze the characteristics of landscape changes at a settlement level. Task 2 engaged participants in seeking ways for the village to develop sustainably by introducing the abstract concept of sustainability in a more tangible way to participants. From the interviews of Task 3, participants were able to learn from the residents about the context and history of issues, problems, or other situations facing the village.

It is most clearly seen in the qualitative data that interaction with residents and teammates in actual context played a key role in students' knowledge construction. During interviews in the village, residents often complained about problems caused by the WHS listing status, such as a loss of privacy, and they stressed the importance of supporting the residents' particular way of life in the village. The following excerpts illustrate how students enriched their original knowledge and gained better understanding of the village.

Excerpt 1.

Student 1: Do you think Yangdong Village became a better place for living after becoming a World Heritage Site? 
Resident: It looks good from outside but became unpleasant for real residents.

Student 2: Really? What makes it inconvenient?

Resident: We do not have the freedom to change our houses. And sometimes tourists enter the front yard and open the door while I am sleeping inside. That is very unpleasant.

Student 1: Yes, that must be very annoying .... Were there any positive changes?

Resident: The Cultural Heritage Administration has restored old houses and rebuilt traditional buildings that had disappeared. These were good things.

Excerpt 2.

Student 1: The residents differ from us on this issue. I thought that becoming a World Heritage Site involved more benefits than troubles. But it was not true.

Student 3: No - while the benefits they are receiving are indirect, the restrictions on them are direct.

Student 2: That is more critical. Nothing to gain but ... the invasion of privacy was serious.

Student 3: The organization would not solve all problems ... at most, restoration.

Student 2: Becoming a World Heritage Site is not always a case of happily ever after.

A process of knowledge construction was also noted, while students made sense of their experience in interaction with their teammates in the field.

Excerpt 3.

Student 1: How about the cow house now?

Student 2: OK.

Student 1: Should it change or remain as it is?

Student 3: Well, I think that it can be preserved. The roof tiles' color goes well with the surroundings.

Student 1: But it does not necessarily need to stay the same as it is now.

Student 3: True, but if it is a means of living for them, it must remain so.

Student 2: Oh, I see.

Student 1: But during the pre-fieldwork session, you [Student 3] said that this kind of building structure must change.

The contents and design of the student tasks should have influenced the participants' learning processes in the field. Cohen (1994) pointed out that controversial and illdefined tasks better support productive interaction than well-structured tasks with one right answer. In fact, the free and open exchange of ideas among students was most evident during Task 2, where multiple interpretations of the same feature were possible, and data could be collected from all of the surrounding area. In the similar lines, 92.9\% of participants responded that collaboration among team members was essential for completing the tasks, showing the critical role of cooperation (Table 5). In conclusion, 
the inquiry process embedded into the fieldwork gave the participants - both individually and collaboratively - the opportunity to make sense of the data, and to explore different perspectives on the village relating to geographical issues.

Inquiry-related behaviour. In regard to the impact on inquiry-related behaviors, the majority of participants responded that, while conducting the field tasks, they became more active $(84.1 \%)$, more adventurous $(80.7 \%)$, more talkative $(79.6 \%)$, and more responsible for what was happening $(88.7 \%)$. The fieldwork tasks, during which participants in small groups needed to make all necessary decisions by themselves, were designed to encourage participants to become more involved and active in the learning process. In particular, the interviews carried out in Task 3 were meant to help students to step out of their comfort zones and to be more independent.

Futhermore, the ambiguous nature of Task 2, involving participants' subjective judgments and personal values, intended participants to discuss issues with each other more intensely and for a longer time.

Participants pointed out that the project had helped them learn various methods for field investigation and technology use (89.4\% and $77.9 \%$ respectively). It is clear that participants had the opportunity to develop a range of research skills and data collection methods, including those relating to questionnaires, photographs, field observations, interviews, and mapping collected samples. They also developed other, more broadly transferable skills, such as independent learning and problem solving.

\section{Mobile Technology for Inquiry-based Fieldwork}

Location guidance. The most basic form of mobile support for this study was location guidance. Location guidance covers a range of support involving locationbased information, including identification of current geographical location ("location identification") and routes to the next destination ("route planning"). Mobile devices not only allowed participants to find their current locations, and directions to their destination, but also helped them access additional information, not immediately apparent, about their surroundings. The following are often-observed conversations during performances of Task 2 , which required students to find their real locations on the map.

\section{Excerpt 4.}

Student 1: Is this where we are?

Student 2: Is this what I just did?

Student 1: This is Mucheomdang and this is here.

\section{Excerpt 5 .}

Student 1: This house number should be 40-1!

Student 2: 40-1? We cannot tell with this paper map.

Student 1: No! I mean that there are house numbers on [the map of] the iPad. If you click one by one [through the house icons], then we will see.

The participants tended to use location guidance more often in the early stage of their on-site field study. Most dialogues regarding location guidance took place in the first 
half of time spent in the field. As the students became more familiar with the environment, there was less finding their way involved.

Data capture. Data capture includes students' data collection, editing, and transmission and interpretation activities in carrying out the three tasks for which they used Collector and Google Forms as well as the iPads' built-in cameras and voice recorders. Data capture is a student inquiry process that is most commonly supported by mobile devices. Here is a typical example of data capture dialogue.

Excerpt 6.

Student 1: May we record a video of you while you talk with us?

Resident: Video?

Student 2: It will only be used for our report. We will not use it elsewhere.

Resident: OK.

This study also found that Collector enabled students to capture data such as images and videos at any time and any place, and to save, view, and edit the data in the field. Collector also helped students find the spatial distributions and patterns of their collected data. In particular, while the students were conducting quantitative data collection for Task 1, Collector prompted them to identify spatial distributions and patterns of change in the village's traditional houses. However, since finding spatial patterns or relationships based on collected data was not an explicit part of Task 1, pattern seeking was more implicit.

\section{Excerpt 7.}

Student 1: The houses in this area are all B\&Bs.

Student 2: Yes, look! These are all gray. Nothing else!

Student 1: If you go further, they are all private houses. There is only one B\&B there.

Student 2: Right!

Student 3: We have only three whites!

Similarly, the automated graphs-and-reports function of Google Forms, employed in Task 3, enabled the students to easily understand the totality of the responses. The Google Form automatically collated the datasets to create an average set of data values across the groups.

Metacognition. A third function of mobile support is metacognition, including monitoring, clarification and planning. Mobile technologies with wireless network connections helped students watch and evaluate the progress of their data collection, and to take actions based on these evaluations, while in the field.

\section{Excerpt 8.}

Student 1: We have finished around here. Did not cover there.

Student 2: Other teams have done a lot ... he-he.

Student 3: Do not worry. We are OK.

Student 2: Really? We also missed there.

Student 1: We have done many .... We need to focus here. We have not started there yet. 
Under mobile and wireless network environment, monitoring not only can be extended to the progres of other teams' tasks, but also can bridge student learning across time and across location. The conversation below illustrates that monitoring actions, especially comparing them across teams, function as "asynchronous collaborative learning." Because the participants could often access and examine the data collected by other teams, they learned from each other and further solved problems by observation and imitation. This helped them determine the type of data that would be right for Task 2 .

Excerpt 9.

Student 1: They [other members of the same group] already checked [the houses] here.

Student 2: Good!

Student 1: They did a lot. They completed this area. We'd better go back then.

Student 3: Yes, you are right. They must have been finishing around here.

Student 1: Well, we had better get back later. There are many unchecked houses left up there.

Student 3: Oh, Team A is going so fast.

Student 1: Yes, we have not started interviewing yet.

\section{Excerpt 10.}

Student 1: Look! This team placed many red dots around here. What are these?

Student 2: These are features that should change.

Student 1: But there is no memo about them. Aha! There it is. What the heck did they do? What is it? Is it about a gate?

Student 2: What could it be?

Student 1: That the gate is shabby?

Communication. Lastly, the students used their own devices (i.e., cell phones) for communication purposes. Examples include the following.

\section{Excerpt 11.}

Student 1: Hello? We are working on the last house.

Student 2: Can you help us? There is no house number 50.

Student 1: OK. We will search. Where are you now?

In the relevant phases, students shared experiences, discussed progress, results and issues, and incorporated feedback.

\section{Discussion}

This study suggests a level-specific and practical guideline for teachers who must face the problems involved with designing inquiry-based fieldwork projects. In Table 1, the study provides step-by-step suggestions for factors to consider when designing inquiry-based fieldwork, whether educators select teacher-led or students-led approaches. This study emphasizes the importance of clearly identifying issues and problems in the investigation area, and of student activities promoting discovery experience and collaboration. It also emphasizes environmental challenges and facilitators including instructional scaffolding and technical supports for best results 
(Catling \& Lee, 2016; Chatterjea, 2012; France et al., 2015; Gao, Liu, \& Paas, 2016; Hedberg, 2014; Hus \& Chen, 2010; Lee \& Oh, 2016; Marra et al., 2017; Marshall et al., 2009; Raath \& Golightly, 2017; Roberts, 2013). Following the suggested guidelines, this study supplied an examplary fieldwork project for high-school students to actively participate in a field inquiry by working through posing questions, designing investigations, collecting and analyzing data, drawing conclusion, and sharing findings. Since most Korean students rarely have the opportunity to collect primary data through either field observation or direct communication with respondents, this study followed the "middle way" of inquiry-based learning, blending student-centered and teachercentered approaches. Especially, students' data-collection processes in the field had the support of mobile technology, including the ArcGIS Collector application and Google Forms.

The results of analysis on the second research question showed that participation in the project enabled students to develop more awareness and to become better informed of the investigation area (i.e., Yangdong Village). In addition, the post-project survey dealing with self-evaluative aspects in a large cohort $(\mathrm{N}=86)$ showed that the participating students found significant benefits in technology, inquiry, and teamwork skills. In particular, the students said that they became more active, more adventurous, more talkative, and more responsible for their learning $(88.7 \%)$ while they were conducting the field tasks.

The findings of this study are comparable with some earlier studies. Researchers emphasize role of direct experience, active learning and inquiry process of fieldwork in the growth of geographical understanding (Herrick, 2010; Hope, 2009). For example, Lee, Oh, \& Choi (2017) reported that the students who completed an inquiry-based fieldwork in a sand dune showed a significant improvement in the pre- and postcomprehen test. They illustrated that the students could improve their knowledge about the investigation area not only through various pre-fieldwork activities providing information about the area, but also through visually checking and communicating the information in the real enviornment. In addition, Raath \& Golightly (2017) emphasize the importance of knowledge formed through inquiry process. They argued that a series of inquiry processes including problem-identification, development of research methods, and engagement in data collection and interpretation by themselves can empower students to gain in-depth knowledge of the topic. The students who participated in the current study would also be able to deepen and construct their knowledge about the village by collecting authentic data in the village, talking with the residents, and communicating the collected data with their teammates.

This study also supports the view of Hupy (2011) that collaboration and cooperation are essential geographic skills built up through fieldwork. However, collaboration in fieldwork using wireless technology differs from that of traditional forms of fieldwork. For example, excerpt 10 shows a type of peer-to-peer content access and adaptation system (Yang, 2006), by which students can learn from each other synchronously or asynchronously. It is a natural process of learning in ubiquitous learning environments, and one that has the potential to serve as a powerful mechanism of knowledge transfer among students using mobile technology in the field. 
The results of analysis on third research question showed that technological support was prominent in three areas of the field inquiry: location identification, data capture, and monitoring. The types of mobile-technological support represent what kind of mobile technology students used, and for which tasks. That is, since exploring in an unknown environment, and collecting field data using mobile devices, were key requirements for the field tasks, the use of mobile technology would be prominent in finding locations and collecting data. In other words, to carry out Tasks 1 and 2, students needed to explore an unfamiliar environment and to record various types of data in the correct locations. On the other hand, there were also cases where students used the functions because they were available. For example, although it was necessary to check the progress of data collection, students would not have done so easily if the progress were not displayed on their iPad screens in real time. Thus, it is noteworthy that the mobile-technological functionalities students used during their field inquiry reflect not only the characteristics of the task but also the type of mobile technology involved with the project.

Lastly, Collector also enabled students to collect enough data in the short amount of time available, based on customized data entry procedures. It speeded up data collection processes in the fieldwork by minimizing the difficulty of collecting accurate data, and by allowing students to execute and automate data collection step by step. This finding concurs with the study of Chatterjea (2012) who reported similar advantages of using mobile technology to collect data in large areas in a short time. In addition, she pointed out, using omnipresent devices might give students control, ownership and management of their inquiry, and make them more active and independent leaners.

\section{Conclusion}

Fieldwork has been a unique teaching and learning strategy for geography education, and an essential research method for geography as a discipline (Fuller, Rawlinson, \& Bevan, 2000; Kent, Gilbertson, \& Hunt, 1997; Oost, De Vries, \& Van der Schee, 2011). However, simply taking students out into the field is not enough for them to be able to learn (Lonergan \& Andresen, 1988). There are bound to be certain circumstances under which fieldwork is particularly effective for students. The role of pedagogic research is to name these circumstances so that best practices can incorporate them. Researchers in geography education have emphasized the effectiveness of inquiry-based approaches for fieldwork. In such approaches, students are responsible for their own data collection, in answer to a relevant research question (Harris \& Tweed, 2010; Raath \& Golightly, 2017). However, little research has addressed how best we can design and implement inquiry-based fieldwork, or the effects of such a practice at secondary school levels. Technology-enhanced, inquiry-based fieldwork has been even rarer. Bednarz et al. (2013) argued for more studies to show how geographical fieldwork can best incorporate mobile technologies. In fact, many research questions are still unanswered, especially about geospatial technologies (GST) and learning. For example, Baker et al. (2015) have asked, "What are the best practices for the design of curriculum and instructional strategies that use GST?" They have also asked, "What are the essential geospatial tasks and processes needed to support critical thinking or geospatial thinking 
and reasoning at specific grade levels or subject areas?"

This study is important for several reasons. First, to the best of the author's knowledge, it is the first study to report on how inquiry-based fieldwork using mobile technology enabled students to develop more awareness of the investigation area. In addition, the post-fieldwork survey showed that participation in the project had not only increased students' inquiry skills, but also led to an increase of inquiry-related behaviors. This result reinforces that inquiry-based fieldwork is effective in improving students' $21^{\text {st }}$ century skills, particularly skills such as collaboration, spirit of challenge, independence, and responsibility for learning (Lee, 2016; www.p21.org). Second, the results of this study can contribute to existing research on how the relationship between inquiry-based activities and mobile technology can facilitate students' learning processes. As shown in the results, it was not necessarily technology itself but the relationship between technology and pedagogical design that afforded possibilities for better inquiry-based learning, and this understanding can have a significant impact on teaching practice. Third, the results of analysis on students' use of mobile technologies in fieldwork will contribute to a better understanding of the uses of mobile devices in fieldwork activities. Most research on this topic has explored pedagogical affordances of mobile technology by developing a conceptual framework and a literature review that serves as its backbone, or by conducting case studies. But this has rarely been theorytesting case study research.

\section{Acknowledgement}

This work was supported by the Ministery of Education of the Republic of Korea and the National Research Foundation of Korea (NRF-2016S1A5A2A01022933).

\section{References}

Baker, T. R., Battersby, S., Bednarz, S. W., Bodzin, A. M., Kolvoord, B., Moore, D., Sinton, D., and Uttal, D. (2015). A research agenda for geospatial technologies and learning. Journal of Geography, 114(3), 118-130.

Bednarz, S. W., S. Heffron, and N. T. Huynh, N.T., (2013). A road map for 21 st century geography education: Geography education research (A report from the Geography Education Research Committee of the Road Map for 21st Century Geography Education Project). Washington, DC: Association of American Geographers.

Bermingham, A. (2016). Investigating the extent to which student-led inquiry is supported by fieldwork booklet design. Geographical Education, 29, 33-39.

Chang, C-H., Chatterjeaa, K., Gohb, D. H-L., Thengb, Y. L., Limc, E. P., Sund, A., Razikinb, K., Kimb, T. N. Q., \& Nguyenb, Q. N. (2012). Lessons from learner experiences in a field-based inquiry in geography using mobile devices. International Research in Geographical and Environmental Education, 21(1), 41-58.

Chatterjea, K. 2008. Virtual workplace for learning in Singapore. In P. Zemliansky \& K. St Amant (Eds.), Handbook of research on virtual workplaces and the new nature of business practices (pp. 301-316). Hershey, PA: IGI Global.

Chatterjea, K. 2012. Use of mobile devices for spatially- cognizant and collaborative fieldwork in geography. Review of International Geographical Education Online, 2(3), 303-325. 
Lee, Jongwon (2020) / Designing an Inquiry-based Fieldwork Project for Students Using Mobile Techno....

Cliffe, A. D. (2017). A review of the benefits and drawbacks to virtual field guides in today's Geoscience higher education environment. International Journal of Education Technology in Higher Education, 14, 28, https://doi.org/10.1186/s41239-017-0066-x

Cochrane, T., \& Bateman, R. (2010). Smartphones give you wings: Pedagogical affordances of mobile Web 2.0. Australian Journal of Educational Technology, 26(1), 1-14.

Cohen, E. G. (1994). Restructuring the classroom: Conditions for productive small groups. Review of Educational Research, 64(1), 1-35.

Creswell, J. W., \& Clark, V. L. (2017). Designing and conducting mixed methods research. Thousand Oaks, CA: Sage Publications.

Dillenbourg, P. (1999). What do you mean by collaborative learning? In P. Dillenbourg (Ed.), Collaborative-learning: Cognitive and Computational Approaches (pp. 1-19). Oxford: Elsevier.

Fletcher, S., France, D., Moore, K., \& Robinson, G. (2007). Practitioner perspectives on the use of technology in fieldwork teaching. Journal of Geography in Higher Education, 31(2), 319-330.

France, D., Whalley, W. B., Mauchline, A., Powell, V., Welsh, K., Lerczak, A., Park, J., \& Bednarz, R., (2015). Enhancing fieldwork learning using mobile technologies, Cham: Springer.

Fuller, I., \& France, D. (2016). Does digital video enhance student learning in field-based experiments and develop graduate attributes beyond the classroom? Journal of Geography in Higher Education, 40(2), 193-206

Fuller, I., Rawlinson, S., \& Bevan, R. (2000). Evaluation of student learning experiences in physical geography fieldwork: Paddling or pedagogy? Journal of Geography in Higher Education, 24(2), 199-215.

Gao, Y., Liu, T.-C., \& Paas, F. (2016). Effects of mode of target task selection on learning about plants in a mobile learning environment: Effortful manual selection versus effortless QRcode selection. Journal of Educational Psychology, 108(5), 694-704.

Goh, D. H. Razikin, K., Lee, C. S., Lim, E. P., Chatterjea, K., \& Chang, C. H. (2012). Evaluating the use of a mobile annotation system for geography education. The Electronic Library, 30(5), 589-607.

Hedberg, J. G. (2014). Extending the pedagogy of mobility. Educational Media International, 51(3), 237-253.

Herrick, C. (2010). Lost in the field: Ensuring student learning in the 'threntened' geography fieldtrip. AREA, 42(1), 108-116.

Hope, M. (2009). The importance of direct experience: A philosophical defence of fieldwork in human geography, Journal of Geography in Higher Education, 33(2), 169-182.

Hsu, T. Y., \& Chen, C. M. (2010). A mobile learning module for high school fieldwork. Journal of Geography, 109(4), 141-149.

Hupy J. P. (2011). Teaching geographic concepts through fieldwork and competition. Journal of Geography, 110(3), 131-135. 
Jarvis, C., Tate, N., Dickie, J., \& Brown, G. (2016). Mobile learning in a human geography field course. Journal of Geography, 115(2), 61-71.

Johnson, K. (2003). Designing language teaching tasks, Basingstoke: Palgrave Macmillan.s[ep:

Jones, A. C., Scanlon, E., \& Clough, G., (2013). Mobile learning: Two case studies of supporting inquiry learning in informal and semiformal settings, Computers \& Education, 61(1), 21-32.

Jong, M. S., \& Tsai, C. (2016). Understanding the concerns of teachers about leveraging mobile technology to facilitate outdoor social inquiry learning: The EduVenture experience. Interactive Learning Environments, 24(2), 328-344.

Kang, D., Kim, M., \& Park, M. (2011). A settlement pattern and consciousness change of Yangdong village connected with institutionalization. The Journal of Korea Planners Association, 46(5), 93-111.

Kent, M., Gilbertson, D. D., \& Hunt, C. O. (1997). Fieldwork in geography teaching: A critical review of the literature and approaches. Journal of Geography in Higher Education, 21(3), 313-332.

Kirschner, P. A., Sweller, J., \& Clark, R. E. (2006). Why minimal guidance during instruction does not work: An analysis of the failure of constructivist, discovery, problem-based, experiential, and inquiry-based teaching. Educational Psychology, 41(2), 75-86.

Klopfer, E., Squire, K., \& Jenkins, H. (2008). Environmental detectives - The development of an augmented reality platform for environmental simulations. Educational Research Technology and Development, 56(2), 1042-1629.

Kwan, T., \& So, M. (2008). Environmental learning using a problem-based approach in the field: A case study of a Hong Kong school. International Research in Geographical and Environmental Education, 17(2), 93-113.

Lee, J. (2016). The roles and challenges of geography fieldwork for the $21^{\text {st }}$ century skills. The Journal of the Korean Association of Geographical and Environmental Education, 24(1), 99-117.

Lee, J., \& Catling, S. (2016). What do geography textbook authors in England consider when they design content and select case studies? International Research in Geographical and Environmental Education, 26(4), 342-256.

Lee, J., Oh, S., \& Choi, K. (2017). Students' experiences with investigative fieldwork activity of coastal sand dunes. Journal of Korean Association of Geographical and Environmental Education, 25(2), 129-150.

Lonergan, N., \& Andresen, L. W. (1988). Field-based education: Some theoretical considerations. Higher Education Research and Development, 7(1), 63-77.

Looi, C. K., Seow, P., Zhang, B. H., So, H. J., Chen, W., \& Wong, L. H. (2010). Leveraging mobile technology for sustainable seamless learning: A research agenda. British Journal of Educational Technology, 41(2), 154-169.

Marra, W. A., van de Grint, L., Alberti, K., \& Karssenberg, D. (2017). Using GIS in an Earth Science field course for quantitative exploration, data management and digital mapping. Journal of Geography in Higher Education, 41(2), 213-229. 
Lee, Jongwon (2020) / Designing an Inquiry-based Fieldwork Project for Students Using Mobile Techno....

Marshall, J. C., Smart, J., \& Horton, R. M. (2009). The design and validation of EQUIP: An instrument to assess inquiry-based instruction. International Journal of Science and Mathematics Education, 8(2), 299-321.

McClain, L. R., \& Zimmerman, H. T. (2016). Technology-mediated engagement with nature: Sensory and social engagement with the outdoors supported through an electronic trailguide. International Journal of Science Education, 6(4), 385-399.

Medizini, A., Meishar-Tal, H. \& Sneh, Y. (2015). Use of mobile technologies as support tools for geography field trips. International Research in Geographical and Environmental Education, 24(1), 13-23.

Oh, S. M., \& Lee, J. (2014). Geography fieldwork in secondary schools: Aims, types, planning and constraints. Journal of the Korean Geographical Society, 22(1), 111-130.

Oost, K., De Vries, B., \& Van der Schee, J. (2011). Enquiry-driven fieldwork as a rich and powerful teaching strategy - school practices in secondary geography education in the Netherlands. International Research in Geographical and Environmental Education, 20(4), 309-325.

Parsons, D. (2014). The future of mobile learning and implications for education and training. In M. Ally \& A. Tsinakos (Eds.), Perspectives on open and distance learning: Increasing access through mobile learning (pp. 217-229). Col, Athabasca University.

Patten, B., Sa' nches, I. A., \& Tangney, B. (2006). Designing collaborative, constructivist and contextual applications for handheld devices. Computers and Education, 46(3), 294-308.

Perkins, D. (2009). Making learning whole: How seven principles of teaching can transform education. San Francisco, CA: Jossey-Bass.

Raath, S., \& Golightly, A. (2017). Geography education students' experiences with a problembased learning fieldwork activity. Journal of Geography, 116(5), 217-225.

Reid, N. \& Yang, M. J. (2002). The solving of problems in chemistry: The more open-ended problems. Research in Science \& Technological Education, 20(1), 83-98.

Roberts, M. (2013). Geography through enquiry: Approaches to teaching and learning in the secondary school, Sheffield, UK: The Geographical Association.

Sadeh, I. \& M. Zion. (2012). Which type of inquiry project do high school biology students prefer: Open or guided? Research in Science Education, 42(5), 831-848.

Song, Y., Wong, L-H., \& Looi, C-K. (2012). Fostering personalized learning in science inquiry supported by mobile technologies. Education Technology Research Development, 60, 679-701.

Suárez, Á., Specht, M., Prinsen, F., Kalz, M., \& Ternier, S. (2018). A review of the types of mobile activities in mobile inquiry-based learning. Computers \& Education, 118, 38-55.

Sung, H-Y., Hwang, G-J., \& Chang, Y-C. (2016). Development of a mobile learning system based on a collaborative problem-posing strategy. Interactive Learning Environment, 24(3), 456-471.

Sweller, J., \& Cooper, G. A. (1985). The use of worked examples as a substitute for problem solving in learning algebra. Cognition and Instruction, 2(1), 59-80. 
Tally, B., (2007). Digital technology and the end of social studies education. Theory \& Research in Social Education, 35(2), 305-321,

Trautmann, N., MaKinster, J., \& Avery, L. (2004). What makes inquiry so hard? Paper presented at the annual meeting of the National Association for Research in Science Teaching, Vancouver, BC, Canada, April 1-3.

Vygotsky, L. S. (1978), Interaction between learning and development, In M. Cole, V. JohnSteiner, S. Scribner \& E. Souberman (Eds.), Mind in society: The development of higher psychological processes (pp. 79-91). Cambridge, MA: Harvard University Press.

Webster, A., Beveridge, M., \& Reed, M. (1996). Managing the literacy curriculum, London: Routledge.

Wellsh, K. E., Mauchline, A. L., France, D., Powell, V., Whalley, W. B., \& Park, J. (2018), Would Bring Your Own Device (BYOD) be welcomed by undergraduate students to support their learning during fieldwork? Journal of Geography in Higher Education, 42(3), 356-371.

Welsh, K. E., Mauchline, A. L., Park, J., Whalley, W. B. \& France, D. (2013). Enhancing fieldwork learning with technology: practitioner's perspectives. Journal of Geography in Higher Education, 37(3), 399-415.

Welsh, K. E., Mauchline, A. L., Powell, V., France, D., Park, J. L., \& Vhalley, W. D. (2015). Student perceptions of iPads as mobile learning devices for fieldwork. Journal of Geography in Higher Education, 39(3), 450-469.

Yang, J. C., \& Lin, Y. L. (2010). Development and evaluation of an interactive mobile learning environment with shared display groupware. Educational Technology \& Society, 13(1), 195-207.

Yang, S. J. H. (2006). Context aware ubiquitous learning environments for peer-to-peer collaborative learning. Educational Technology \& Society, 9(1), 188-201.

\section{Biographical Statement}

Jongwon LEE is a professor of Social Studies Education (geography education major) at Ewha Womans University, Seoul. Prior to joining Ewha Womans University in 2006, he worked for the American Association of Geographers in Washington, DC as an education fellow from 2005 to 2006 . He received his B.A. (1997) and M.A. (2000) degrees in geography education from Seoul National University. And he also completed his Ph.D. (2005) in geography education from Texas A\&M University by developing the Spatial Thinking Ability Test (STAT) and assessing the impact of GIS learning on spatial thinking abilities. His current research interests include inquiry, fieldwork, and technology. He is also passionate about designing innovative lesson plans and new teaching ideas and sharing them with leading teachers. He has served as Secretary of the Commission on Geographical Education (CGE) of the International Geographical Union (IGU) since August 2016. 